\title{
Controlled Clinical Trial of L-Dopa and Nafoxidine in Advanced Breast Cancer: An E.O.R.T.C. Study
}

\author{
E. ENGELSMAN, J. C. HEUSON, J. BLONK-VAN DER WIJST, A. DROCHMANS, H. MAASS, \\ F. CHEIX, L. G. SOBRINHO, H. NOWAKOWSKI
}

trial the use of drugs which depress hypothalamic activity, and are thereby likely to enhance prolactin secretion (tranquillizers and antihypertensive drugs, such as reserpine derivatives), was strictly prohibited. Because pyridoxine antagonizes the effects of L-dopa vitamin preparations containing this compound were not allowed. Only salicylates and local irradition were allowed for control of pain and only barbiturates as sedatives. Patients with severe pain that might not be controlled effectively by these measures were excluded from the study.

L-Dopa was given by mouth, starting with a daily dose of $750 \mathrm{mg}$ divided in three $250-\mathrm{mg}$ doses taken with meals. After one week a daily dose of $1500 \mathrm{mg}$ was given in three $500-\mathrm{mg}$ doses. This dose was the same as that reported in other papers for the same therapeutic use. I Lopa treatment was to be discontinued if the disease remained progressive, it was to be given for at least six weeks if the disease remained unchanged, and was to be continued if regression occurred. Nafoxidine $60 \mathrm{mg}$ three times a day was given orally.

\section{Introduction}

Prolactin is an important factor in experimental mammary tumours in mice and rats. ${ }^{1-4}$ In man hints favour its possible role in breast carcinogenesis, ${ }^{5}$ but nothing is known about the part played by prolactin in maintaining the growth of established breast cancer. ${ }^{6}$ Nevertheless, L-dopa, which lowers plasma prolactin levels in man, ${ }^{7-10}$ has been reported to produce beneficial effects in patients with breast cancer. ${ }^{11-14}$ On this evidence the E.O.R.T.C. Breast Cancer Co-operative Group undertook a trial of $\mathrm{L}$-dopa in advanced breast cancer to investigate whether this drug could produce objective remissions and to compare its potential value with nafoxidine, a reference compound of known efficacy. ${ }^{15-17}$ We present here the results of this controlled clinical trial.

\section{Patients and Methods}

The criteria for patients' eligibility, the method of assessing therapeutic response, and the technique of stratification and randomization were the same as those detailed by Heuson et al. ${ }^{17}$ (this issue). During the Department of Internal Medicine, Netherlands Cancer Institute,
Antoni van Leeuwenhoek Ziekenhuis, Amsterdam, The Nether-
lands
E. ENGELSMAN, M.D.

Institut Jules Bordet, Brussels, Belgium

J. C. HEUSON, M.D.

Department of Internal Medicine, Rotterdamsch Radio-Therapeutisch Instituut, Rotterdam, The Netherlands

J. BLONK-VAN DER WIJST, M.D.

Academisch Ziekenhuis Sint-Rafaël, Leuven, Belgium

A. DROCHMANS, M.D.

Universitäts Krankenhaus, Hamburg, Germany

H. MAASS, M.D., Physician

H. NOWAKOWSKI, M.D.

Centre Léon-Bérard, Lyon, France

F. CHEIX, M.D.

Portuguese Institute of Oncology, Francisco Gentil, Lisbon, Portugal L. G. SOBRINHO, M.D.

\section{Results}

Originally 49 patients were entered into each treatment group. After review of all the patients' records 76 patients were considered evaluable, 36 in the nafoxidine group and 40 in the L-dopa group. The 22 patients excluded consisted of five on nafoxidine who died within a week of starting the trial, one on each drug who had central nervous system involvement, two on each drug who were lost to follow-up, three or. nafoxidine and five on L-dopa who had been castrated less than two Jears before, and two on nafoxidine and one on L-dopa who had other hormones added.

There were differences between the two treatment groups (see table): the disease-free interval was significantly shorter in the nafoxidine-treated patients $(P=0.006$; Mantel-Haenszel test) and visceral metastases predominated in the L-dopa group, though not significantly $(P=0.08)$. These differences would tend to favour L-dopa.

Objective remissions occurred in seven out of 36 patients $(19 \%)$ on nafoxidine. Remission lasted a mean of nine months (median seven months). No objective remissions were obtained with $L$-dopa. In those in whom treatment failed both treatments had lasted for a mean of six weeks, with a median of 7.6 weeks in the nafoxidine group and 7.5 weeks in the L-dopa group. The difference in effectiveness between the two drugs was highly significant $(P<0.01$; Fisher's exact probability test, two-sided).

Side effects ascribed to the drugs were seen in about half the patients. Nausea and vomiting were frequent complaints with L-dopa (15 cases); with nafoxidine skin changes were the major cause of complaints. Phototoxicity was most prominent in patients in remission on nafoxidine treatment (six cases) who had been given the drug for prolonged periods.

\section{Discussion}

Our results show that no objective remission was obtained in a group of 40 patients with advanced breast cancer treated with oral L-dopa. The $19 \%$ remission rate in the control group treated with nafoxidine shows that our patient population was not unusual and responded normally to an endocrine-related compound of known efficacy.

L-Dopa's failure to achieve objective remissions in patients with breast cancer was not unexpected but seemed worth being firmly established in view of reported claims to the contrary (see Introduction). Our results seem to settle the question because our study covered a substantial number of patients whereas other series were small and patients' responses were not 
Data on 76 Patients evaluated in Trial

\begin{tabular}{|c|c|c|c|c|c|c|c|c|c|c|c|c|c|c|c|c|}
\hline & \multicolumn{4}{|c|}{$\begin{array}{c}\text { Age } \\
\text { (Years) }\end{array}$} & \multicolumn{4}{|c|}{ Years after Menopause } & \multicolumn{5}{|c|}{$\begin{array}{c}\text { Disease-free Interval } \\
\text { (Months) }\end{array}$} & \multicolumn{3}{|c|}{$\begin{array}{c}\text { Dominant Site of Lesions } \\
\text { (No. of Patients) }\end{array}$} \\
\hline & 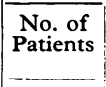 & Mean & Median & Range & $\begin{array}{c}\text { No. of } \\
\text { Patients }\end{array}$ & Mean & Median & Range & $\overline{\begin{array}{c}\text { No. of } \\
\text { Patients }\end{array}}$ & Mean & Median & Range & $\begin{array}{c}\text { No. with } \\
\text { No } \\
\text { Interval }\end{array}$ & $\begin{array}{c}\text { Soft } \\
\text { Tissues }\end{array}$ & Osseous & Visceral \\
\hline $\begin{array}{l}\text { Nafoxidine } \\
\text { L-Dopa }\end{array}$ & $\begin{array}{l}36 \\
40\end{array}$ & $\begin{array}{l}61 \cdot 4 \\
64 \cdot 8\end{array}$ & $\begin{array}{l}64 \\
65\end{array}$ & $\begin{array}{l}39-76 \\
49-81\end{array}$ & $\begin{array}{l}36 \\
40\end{array}$ & $\begin{array}{l}13 \cdot 8 \\
15 \cdot 9\end{array}$ & $\begin{array}{l}15 \\
16\end{array}$ & $\begin{array}{l}2-31 \\
2-46\end{array}$ & $\begin{array}{l}27 \\
33\end{array}$ & $\begin{array}{l}23 \cdot 2 \\
47 \cdot 1\end{array}$ & $\begin{array}{l}22 \\
29\end{array}$ & $\begin{array}{l}4-92 \\
4-165\end{array}$ & $\begin{array}{l}9 \\
7\end{array}$ & $\begin{array}{l}9 \\
6\end{array}$ & $\begin{array}{r}11 \\
6\end{array}$ & $\begin{array}{l}16 \\
28\end{array}$ \\
\hline
\end{tabular}

reviewed independently. To our knowledge these small series have not been expanded and in at least one of them no new remission has been obtained. ${ }^{18}$

We did not expect to obtain remissions from $\mathrm{L}$-dopa because it is a poor inhibitor of prolactin secretion. Rozencweig et al. ${ }^{10}$ showed that L-dopa produced a saw-tooth effect on blood prolactin levels, with decreases followed by large rebounds. Bromocriptine (CB 154), however, steadily depressed the blood prolactin level down to $25 \%$ of the pretreatment level in postmenopausal women. ${ }^{10}$ Yet bromocriptine also failed to produce a single case of remission of breast cancer. ${ }^{19}$ If prolactin suppression were therapeutically effective in breast cancer favourable results would be expected from bromocriptine rather than from L-dopa. Indeed, if convincing evidence should be produced showing breast cancer regression under L-dopa treatment other mechanisms than prolactin suppression should be looked for

Do the negative results with L-dopa and bromocriptine rule out any influence of endogenous prolactin on the maintenance of breast cancer growth ? Extreme caution is needed in answering this question because none of these drugs can suppress totally the blood prolactin. ${ }^{10}$ For a definitive answer more potent drugs must become available. Obviously, these results do not exclude the possibility that prolactin might be a key factor in breast carcinogenesis or very early stages of breast cancer development, as suggested by observations in animal models and by the recent report of Kwa et $a l .5$

This study was made by one of the co-operative groups of the
European Organization for Research on Treatment of Cancer (E.O.R.T.C.). The chairman was J. C. Heuson, secretary W. H. Mattheiem, representative of the E.O.R.T.C. council H. J. Tagnon, and co-ordinator $M$. Staquet.

We thank Dr. S. K. Carter, National Cancer Institute, Bethesda, U.S.A., who supplied nafoxidine.

\section{References}

1 Boot, L. M., Induction by Prolactin of Mammary Tumours in Mice. Amsterdam, Noord-Holland Publishing Company, 1969.

${ }^{2}$ Boot, L. M., International fournal of Cancer, 1970, 5, 167.

3 Pearson, O. H., et al., Transactions of the Association of American Physicians, $1969,82,225$.

4 Heuson, J. C., et al., Gynecological Investigation, 1971/72, 2, 130.

5 Kwa, H. G., et al., Lancet, 1974, 1, 433.

Heuson, J. C., in Mammary Cancer and Neuroendocrine Therapy, ed. B. A. Stoll, p. 349. London, Butterworth and Co. Ltd., 1974.

${ }^{7}$ Malarkey, W. B., Jacobs, L. S., and Daughaday, W. H., New England Fournal of Medicine, 1971, 255, 1160.

8 Kleinberg, O. L., Noel, G. L., and Frantz, A. G., Fournal of Clinical Endocrinology and Metabolism, 1971, 33, 873.

${ }^{9}$ Minton, J. P., and Dickey, R. P., Lancet, 1972, 1, 1069.

10 Rinton, J. P., and Dickey, R. P., Lancet, 1972, 1, 1069.

11 Murray, R. M. L., Mozaffarian, G., and Pearson, O. H., in Prolactin and Carcinogenesis, ed. A. R. Boyns and K. Griffiths, p. 158. Cardiff,

Alpha Omega Alpha, 1972.
12 Frantz, A. G., et al., Clinical Research, 1972, 20, 864.

13 Minton, J. P., Cancer, 1971, 33, 358.

14 Stoll, B. A., Lancet, 1974, 1, 431.

E.O.R.T.C. Breast Cancer Group, European Fournal of Cancer, 1972, 8, 387.

${ }_{16}$ Bloom, H. J. G., and Boesen, E., British Medical fournal, 1974, $2,7$.

17 Heuson, J. C., et al., British Medical fournal, 1975, 2, 711 .

18 Pearson, O. H., personal communication, 1975.

19 E.O.R.T.C. Breast Cancer Group, European fournal of Cancer, 1972, 8, 155.

\title{
Intravenous Treatment with Rimiterol and Salbutamol in Asthma
}

\author{
G. E. MARLIN, PAUL TURNER
}

British Medical fournal, 1975, 2, 715-719

\section{Summary}

The bronchodilating efficacies and $\beta_{2}$-adrenoceptor selectivities of rimiterol $\left(0.2,0 \cdot 1\right.$, and $\left.0.05 \mu \mathrm{g} \mathrm{kg}^{-1} \mathrm{~min}^{-1}\right)$ and salbutamol $\left(0 \cdot 1,0.5\right.$, and $\left.0.025 \mu \mathrm{g} \mathrm{kg}^{-1} \mathrm{~min}^{-1}\right)$, intravenously infused for one hour, were determined in five patients with chronic asthma. Each drug infusion produced and maintained a dose-related improvement in forced expiratory volume in one second $\left(F E V_{1}\right)$. A further increase in $\mathrm{FEV}_{1}$ was produced by inhalation of

Department of Clinical Pharmacology, St. Bartholomew's Hospital, London EC1A 7BE

G. E. MARLIN, M.B., M.R.A.C.P., Research Fellow

PAUL TURNER, M.D., F.R.C.P., Professor the same drug by pressurized aerosol at the end of each infusion, which suggested that no resistance had occurred. Similar dose-related increases in heart rate, pulse pressure, and skeletal muscular tremor were produced by each drug. Peak heart rate increases varied greatly between individuals, ranging from 12 to 30 beats/min with the high doses but always less than 10 beats/min with the low doses of each drug. On rimiterol the heart rate reached equilibrium earlier during the infusions and declined more rapidly after they had stopped, thus providing an accurate means for monitoring dosage.

Rimiterol with its short half life-a desirable property for an intravenous drug with respect to safety-may prove to be a valuable bronchodilator in severe asthma when intravenous infusions are indicated.

\section{Introduction}

Severe asthma, refractory to previous bronchodilator treatment, 